chemical engineers will have to produce them to precise specifications. One of the most vital problems of the aircraft industry to-day is that of the production of light alloys and prevention of the corrosion of metals and alloys. This is a matter of the widest industrial importance. There are many other ways in which the aircraft industry has already influenced the chemical industry. This influence is bound to persist, since the aircraft industry is not a gelf-supporting industry, and can only be made selfsupporting by intensive scientific investigation of all its problems.

\section{Site of Newcomen's Engine}

As is fully recognised to-day, it was the invention of the atmospheric steam pumping engine by New. comen that saved many mines from closing down and provided for the first time an engine capable of dealing with water in mines of any considerable depth. The first engine of which we have any record is that delineated in the print bearing the inscription "The Steam Engine near Dudley Castle. Invented by Capt. Savery and Mr. Newcomen. Erected by ye latter 1712. Delin: \& Sculp: by T. Barney 1719." Two copies of this print are preserved, one in the Birmingham Public Library and the other in the Salt Library, Stafford. There is little contemporary evidence as to the site on which this engine was erected, but in a paper read to the Newcomen Society on October 19, at the Science Museum, Dr. T. E. Lones described how with the aid of documents, local histories, parish registers, rate books, etc., and a study of the geology of the district, he has been led to the conclusion that the engine stood in the parish of Tipton, under which is an inclined seam of coal some $24 \mathrm{ft}$. thick. On the Birmingham print, besides the many printed references at the side of the drawing of the engine, is the significant manuscript note: "The beam vibrates 12 times in a minute and each stroke lifts 10 gallons of water 51 yards perpendicularly." This appeared to eliminate much of the area in which the coal is found at greater depths than about $150 \mathrm{ft}$., while further considerations made it possible to determine the position of the engine relative to Dudley Castle. It is, however, probable that unless further documentary evidence, such as might be found in a copy of an old lease, is forthcoming, the exact site will remain unknown. At the conclusion of the meeting it was announced that the next meeting of the Society, on November 16, will be devoted to the reading of a newly discovered diary of the eminent engineer Joshua Field (17871863), while the meeting in December will be the Arkwright bicentenary meeting.

\section{Empire Broadcasting}

IT is now nearly five years since the experimental short-wave transmitter, operating on a wave-length of 24 metres, was established at Chelmsford primarily for two-way working with America. The station has since been in constant use by the British Broadcasting Corporation for experimental broadcasting to various parts of the world to enable No. 3288, VoL. 130] data to be collected on the possibilities of a regular Empire broadcasting service. Following the consideration of a scheme submitted to the Imperial Conference of 1930 , it was decided that the British Broadcasting Corporation should establish an Empire broadcasting station at Daventry. The construction of this station is now well advanced and it is expected that the first transmissions will take place about the middle of December. This new station is intended to provide a programme service which will reach the whole Empire at a reasonable listening time, and for this purpose the Empire has been divided into five zones comprising Australasia, India, Africa, West Africa and Canada. The present arrangements provide for a two hours' programme between 6 P.M. and midnight in each zone. Two transmitters of about twenty kilowatts rating are being installed at Daventry; these will be capable of operation on any one of a series of eight selected wave-lengths varying from 14 metres to 50 metres. These transmitters will supply a number of directional aerial systems, the actual wave-length and direction of transmission in use at any time depending upon the zone to which the programme is being sent, and the prevalence of daylight or darkness along the route. The inauguration of the service is now awaited with much interest. It is anticipated that for a period of about six months the service will be experimental and arrangements will be made to collect reports of reception from selected listeners in all parts of the Empire.

\section{College and Faculty Dissociations}

Mr. A. Moore Hogarth, founder and chairman of the College of Pestology (Incorporated), referring to the paragraph entitled "A 'College' in an Office" in NATURE of October 22, informs us that $\mathrm{H}$. W. Blood Ryan is no longer associated with this institu. tion, and that it has had for a considerable time a laboratory, a reading-room and a museum. The registered office of the College is at 52 Bedford Square, W.C.1, and the laboratory for "Pyorrhœa and Skin Clinics" is at 233 Pentonville Road, N.1. Since receiving the above information, the Hon. Secretary of the International Faculty of Sciences has sent us extracts from the records of meetings of the Council of the Faculty held on September 19 and October 10. At the former meeting, a motion was brought forward relating to the professorial title and academic distinctions of H. W. Blood Ryan, and at the special meeting held on October 10 it was resolved that as evidence of these qualifications had not been furnished to the Council, "his resignation from the office of president and fellowship was unanimously accepted by the Council".

IN reply to an inquiry relating to this communication, Mr. Blood Ryan writes as follows: "Although I resigned all connection with the Faculty on October 10th, and the College of Pestology on September 22nd, I am bound to say that I still consider that there exists no other world-wide body attempting to do those things set forth in the prospectus of the Faculty. I was largely responsible for the addition 